\title{
(2) OPEN ACCESS \\ Manipulated: graphic health warnings on smokeless tobacco in rural India
}

\author{
Michael lacobelli @ ( , Sejal Saraf, Kevin Welding, Katherine Clegg Smith, \\ Joanna E Cohen
}

Department of Health, Behavior and Society, Institute for Global Tobacco Control, Johns Hopkins Bloomberg School of Public Health, Baltimore, Maryland, USA

\section{Correspondence to}

Michael lacobelli, Department of Health, Behavior and Society, Institute for Global Tobacco Control, Johns Hopkins Bloomberg School of Public Health, Baltimore MD 21205, USA; miacobe1@jhu.edu

Received 31 August 2018 Revised 10 December 2018 Accepted 10 January 2019 Published Online First 29 January 2019

\section{Check for updates}

(C) Author(s) (or their employer(s)) 2020. Re-use permitted under CC BY-NC. No commercial re-use. See rights and permissions. Published by BMJ.

To cite: lacobelli M, Saraf S, Welding $\mathrm{K}$, et al. Tob Control 2020;29:241-242.

India is unique in its dual burden of tobacco use. Nearly 200 million individuals use smokeless tobacco (SLT) products in India, ${ }^{1}$ with almost 200000 deaths attributed to SLT use in $2010 .^{2}$ SLT users tend to live in rural areas and have lower levels of education. ${ }^{1}$ India has made substantial strides in tobacco control in recent years, including the 2016 increase in health warning label (HWL) coverage to $85 \%$ on all tobacco products sold, including SLT. The Tobacco Pack Surveillance System (TPackSS) has been monitoring HWL compliance in India and other low-income and middle-income countries

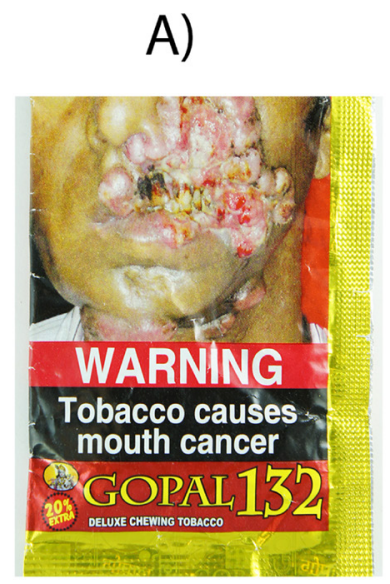

B)

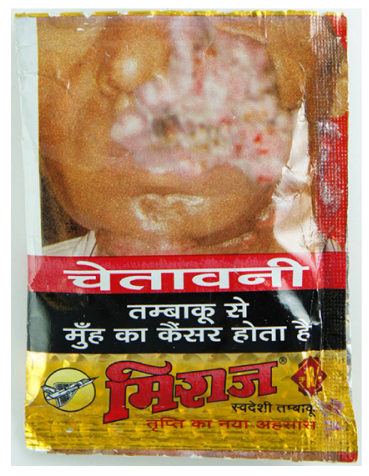

Figure 1 Smokeless tobacco products from rural India with differing health warning label (HWL) printing manipulations. (A) A HWL that is accurately printed, as prescribed by India law; (B) a HWL where the mouth cancer is selectively blurred, maintaining visual clarity for the remaining parts of the HWL; and (C) a HWL that is completely blurred, with sharp text and branding, suggesting these tobacco manufacturers have the ability to print clear packaging. since 2013. After 5600 tobacco products purchased globally, we noticed something truly unique.

Following data collection of 240 unique SLT products purchased in rural India in 2017, 133 (55\%) packs had the current SLT-specific Indian HWL. We observed that several current HWLs on packs appeared to be altered (figure 1). After double coding this sample, eight SLT packages $(6 \%)$ appeared with warnings that were selectively blurred or manipulated in a fashion that obscured parts of the HWL image (figure 1B), and 70 packages (53\%) appeared with entirely blurred warning images (figure 1C). Thirteen packages (10\%) appeared with labels that had some combination of heavy tint, faded colours and stretching. The remaining packages $(n=42)$ displayed an HWL that was free of blurring and colour issues. No such HWL manipulation was found on any cigarette packages collected in India, nor has this been seen with any other tobacco products purchased in 13 other countries. ${ }^{3}$

Data presented here were systematically collected in November 2017 in an adapted TPackSS protocol (originally designed for urban data collection) structured to systematically collect a census of unique SLT products sold in rural towns in five states (Maharashtra, Uttar Pradesh, Assam, Rajasthan and Karnataka). ${ }^{45}$ The five sample states represented almost $40 \%$ of the Indian population and were selected based on political relevance, geographical diversity and prevalence of SLT users. Within each state, five towns were selected for data collection across three different population tiers (3-5), with tier 3 defined as semiurban and tier 4 and 5 as rural. $^{6}$

Prior research in India found that 51\% of unique cigarette packs ${ }^{7}$ and $2 \%$ of unique $\mathrm{SLT}^{8}$ products had compliant HWLs. This gap in compliance is particularly problematic due to the different demographics that use $\mathrm{SLT}^{1}$; the rural literacy rate in the states sampled is $55 \%-70 \%$, with urban rates ranging from $70 \%$ to $85 \%$. ${ }^{9}$ The Framework Convention on Tobacco Control (FCTC) Article 11 recommends graphic warnings as an 'added benefit of potentially reaching people with low levels of literacy'. ${ }^{10}$

Although the Indian law exceeds many of the HWL guidelines in the WHO-FCTC, this deficit in effectual implementation diminishes the ability of HWLs to communicate the health risks of SLT products. We identified a need for regular monitoring of HWLs for accurate printing, with fidelity to the Ministry of Health and Family Welfare 
templates. Given the widespread burden of SLT use, particularly in rural areas, this should be a priority in India.

Acknowledgements We acknowledge and thank Healis Sekhsaria Institute for Public Health who collected these data under the overall supervision of Dr Prakash C Gupta and coordinated by Dr Namrata Puntambekar.

Contributors $\mathrm{Ml}$ was the primary writer of the article. All authors contributed to revising the article critically for important intellectual content. All authors approved of the final version of the paper.

Funding This work was supported with funding from Bloomberg Philanthropies' Bloomberg Initiative to Reduce Tobacco Use (www.bloomberg.org).

Competing interests None declared.

Patient consent Not required.

Provenance and peer review Not commissioned; externally peer reviewed.

Open access This is an open access article distributed in accordance with the Creative Commons Attribution Non Commercial (CC BY-NC 4.0) license, which permits others to distribute, remix, adapt, build upon this work non-commercially, and license their derivative works on different terms, provided the original work is properly cited, appropriate credit is given, any changes made indicated, and the use is non-commercial. See: http://creativecommons.org/licenses/by-nc/4.0/.

ORCID iD

Michael lacobelli http://orcid.org/0000-0003-1058-1104

\section{REFERENCES}

1 Global Adult Tobacco Survey (GATS). Fact Sheet India: 2016-2017. Geneva, Switzerland:World Health Organization. https://mohfw.gov.in/sites/default/files/GATS2\%20FactSheet.pdf. (accessed 30 May 2018).
2 Siddiqi K, Shah S, Abbas SM, et al. Global burden of disease due to smokeless tobacco consumption in adults: analysis of data from 113 countries. BMC Med 2015;13:194.

3 Tobacco Pack Surveillance System (TPackSS). Pack Search.Baltimore, MD: Johns Hopkins Bloomberg School of Public Health.

4 Smith K, Washington C, Brown J, et al. The Tobacco Pack Surveillance System: A Protocol for Assessing Health Warning Compliance, Design Features, and Appeals of Tobacco Packs Sold in Low- and Middle-Income Countries. JMIR Public Health Surveill 2015;1:e8.

5 Tobacco Pack Surveillance System (TPacKSS).TPackSS Smokeless and Bidi Tobacco Field Collection Protocol. Baltimore, MD:Johns Hopkins Bloomberg School of Public Health. https://globaltobaccocontrol.org/tpackss/sites/default/files/2017_India\% 20SLT_Bidi_Field_Protocol_FINAL.pdf (accessed 10 Dec 2018).

6 Ministry of Home Affairs. A-4 Towns and Urban Agglomerations Classified by Population Size Class in 2011: Government of India. http://www.censusindia.gov.in/ 2011census/PCA/A4.html. (accessed 30 May 2018).

7 Tobacco Pack Surveillance System (TPackSS). Health Warning Label Compliance: India-2016 [Fact sheet]. Baltimore, MD: Johns Hopkins Bloomberg School of Public Health. https://globaltobaccocontrol.org/tpackss/sites/default/files/tpackss_ indiawave2_healthwarning_06_28_18.pdf (accessed 27 Nov 2018).

8 Tobacco Pack Surveillance System (TPackSS). Smokeless Tobacco Health Warning Label Compliance: India-2016. Baltimore, MD: Johns Hopkins Bloomberg School of Public Health. https://www.globaltobaccocontrol.org/ tpackss/sites/default/files/tpackss_smokeless_HWL_10_22_2018.pdf (accessed 27 Nov 2018).

9 National Literacy Mission - India. Literates and Literacy Rates-2001 Census (Provisional). http://www.nlm.nic.in/literacy01_nlm.htm (accessed 30 May 2018).

10 World Health Organization. Guidelines for Implementation of Article 11 of the WHO Framework Convention on Tobacco Control (Packaging and labelling of tobacco products: World Health Organization, 2008. 